\title{
IAMJ
}

INTERNATIONAL

AYURVEDIC

MEDICAL JOURNAL

\section{A COMPARATIVE CLINICAL STUDY OF ISHTIKA SWEDA AND NADI SWEDA ALONG WITH RASNADI GUGGULU IN THE MANAGEMENT OF VATAKANTAKA}

\section{$\underline{\text { Gouri Tanksali }}^{1}, \underline{\text { Uma Patil }^{2}}$}

${ }^{1}$ Post Graduate Scholar, ${ }^{2}$ Associate Professor

P.G. Dept, of Kayachikitsa, BLDEA's AVS Ayurveda Mahavidyalaya, Vijayapura, Karnataka, India

\section{Corresponding Author: gourikonnur989@gmail.com}

\section{https://doi.org/10.46607/iamj1409092021}

(Published Online: September 2021)

Open Access

(C) International Ayurvedic Medical Journal, India 2021

Article Received: 31/08//2021 - Peer Reviewed: 06/09/2021 - Accepted for Publication: 07/09/2021

\section{Check for updates}

\section{ABSTRACT}

Vatakantaka is one of the Vata Vyadhi which gives pricking pain in the heels and causes discomfort in the day-today activities. It can be co-related with Calcaneal Spur. It is caused due to wearing high heels and walking with bare feet. Among the various treatment modalities, Abhyanga and Sweda is the best treatment for Vata vyadhi. Hence the present study brings to light the role of Swedana along with Rasnadi Guggulu in the management of Vatakantaka. To evaluate the effect of Istika sweda over Nadi Sweda along with Rasnadi guggulu in management of Vatakantaka. In the present study, 40 patients of vatakantaka were selected incidentally and placed randomly into two groups A and B, with 20 subjects in each group. Group A was treated with Istika Sweda, and Group B were treated with Nadi Sweda along with Rasanadi Guggulu as shamanoushadi for both groups. The effects of treatment provided to the subjects of both groups were significant. Both the treatment methods of Ishtika Sweda and Nadi Sweda showed equally significant effects in the subjects involved in a clinical study.

Keywords: Vatakantaka, Calcaneal Spur, Ishtika sweda, Nadi sweda, Rasnadi guggulu. 


\section{INTRODUCTION}

Ayurveda, the Indian science of medicine has been a very ancient medical practice. It relies on the natural ways of treating the ailments of human beings with the help of medicinal herbs and different procedures which help in healing and recuperation of the body without any altered effects. The world as of now looks towards Ayurveda for unanswered questions in the medical field for solutions.

Here, my work would involve studying a disease

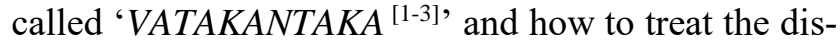
ease with the help of Ayurvedic procedures and 'SHAMANOUSHADHI'. According to Sushruta acharya, when the foot is kept on the ground irregularly vata localized in the $k h u d a($ ankle) gets aggravated and produces pain. This condition is known as vatakantaka. It causes severe pain in the feet and heel which is intolerable for the patients in some cases. The heel pain occurs due to various reasons like Plantar fasciitis, atrophy of heel pad and calcaneal spur etc. Most of these heel pain cases will be associated with Calcaneal spurs. The signs and symptoms of $\mathrm{Va}$ takantaka resemble the condition of Calcaneal spur described by the modern texts. Calcaneal Spur ${ }^{(4)}-$ is additionally called a heel spur. it's a bony outgrowth or bony projection from the under-surface of calcaneal tuberosity.

Vatakantaka is seen as a high prevalence disease these days. The incidence of Calcaneal spur in the normal population is about $32.2 \%{ }^{[5-6]}$. The people in the age group of 20-70 years are the most affected by this condition. It is caused due to wearing high heels and walking with bare feet. Hence, it becomes very much necessary to identify the reasons behind this disease and treat the cause with utmost care to provide relief to the patients.

The Calcaneal spur requires continuous administration of drugs like analgesics, anti-inflammatory drugs and surgical methods if treated with allopathic science. In Ayurveda, the same condition can be treated through non-invasive procedures and economical practices with effective results. Different modalities are explained for the treatment of Vaatakantaka along with Shamanoushadhi. In the present study two methods of swedana namely- Ishtika Swedana with khanji as aavapa dravya along with Rasanadi guggulu as Shamanoushadhi and Nadi Swedana along with Rasnadi guggulu as Shamanoushadhi are taken. Rasnadi guggulu consists of Rasna, Guduchi, Eranda moola, Devadaru, Sunti, Shuddha guggulu all of which act as vaatahara.

Vatakantaka is one among the Vata Vyadhi. General line of treatment of Vata vyadhi is Snehana ( $A b$ hyanga) and Swedana. Rasnadi Guggulu is best Shoolahara and Sthambahara. Nirgundi Taila is Vatahara. Hence, considering all these factors, the following study is undertaken to evaluate the comparative study of Ishtika Sweda and Nadi Sweda along with Rasnadi Guggulu in the management of vatakantak.

\section{MATERIALS AND METHODS}

\section{Source of Materials:}

The following materials were utilized for the clinical trial:

Nirgundi Taila ${ }^{(7)}$, Kanji $^{(8)}$, Rasnadi Guggulu ${ }^{(9)}$

\section{Methods:}

Source of Data: It is a clinical study on the management of Vatakantak and the patients attending the OPD and IPD of B.L.D.E. A's AVS Ayurveda Mahavidyalaya Hospital and Research Center, Vijayapura were taken for the study.

\section{Methods of Data Collection:}

\section{Literary Source:}

This source was collected from Classical texts, Modern texts, and Published articles in reputed journals and Websites.

\section{Clinical Source:}

$>$ Patients suffering from Vatakantaka were randomly selected from OPD and IPD of B.L.D.E. A's AVS Ayurveda Mahavidyalaya Hospital and Research Center, Vijayapura

$>$ Special camps were conducted, and patients were registered for the study.

\section{Drug Source:}

Raw drugs were collected from the market and authenticated by the Department of Dravyaguna, and the formulations were prepared in the department of Rasashastra and Bhaisajya Kalpana, B.L.D.E.A's AVS 
Ayurveda Mahavidyalaya Hospital and Research Center, Vijayapura

Sample Size: A total of 40 patients were subjected to the present clinical study.

\section{Study Design:}

It is an Open, Random Sampling, and Comparative Clinical Trial. Total 40 patients were divided into two groups A \& B having 20 patients in each group

Inclusion Criteria:

- Patients with classical signs and symptoms of $\mathrm{Va}$ takantaka

- Patients of either sex between 20 to 70yrs.

Exclusion Criteria:

1. Patient suffering from a fracture, dislocation of ankle joint.

2. Pregnant women and Lactating mothers.

3. Patients suffering from chronic systemic diseases.

\section{Diagnostic Criteria:}

Patients presenting with the classical signs and symptoms of Vatakantaka such as Ruk pade

In this study, the data was collected from the patients with the help of interviews. The detailed data related to general history, history of past illness, present illness, family history, food habits, history of treatment taken so far etc, were recorded in the proforma of the case sheet. The systemic examination of the patients was also done and findings were recorded as per the proforma.

Laboratory Investigations:

$>$ X-Ray of foot - Lateral View

Interventions:

\begin{tabular}{|c|c|c|}
\hline Group- A & $:$ & Ishtika Sweda \\
\hline Duration & $:$ & 7 days \\
\hline Follow up & $:$ & $7^{\text {th }}$ day \\
\hline Total duration & 1: & 30 days \\
\hline Group- B & : & Nadi Sweda \\
\hline Duration & : & 7 days \\
\hline Follow up & $:$ & $7^{\text {th }}$ day \\
\hline Total duration & & 30 days \\
\hline $\begin{array}{l}\text { FOR BOTH T } \\
G U L U\end{array}$ & THE & GROUPS: $\quad R A S N A D I G U G-$ \\
\hline Dosage & $:$ & $500 \mathrm{mg}$ twice daily \\
\hline \multicolumn{3}{|c|}{ Aushada sevana kala : After Food } \\
\hline Route & : & Oral \\
\hline
\end{tabular}

$\begin{array}{lcc}\text { Anupana } & : & \text { Ushnodaka } \\ \text { Duration } & : & 30 \text { days } \\ \text { Follow up } & : & 30^{\text {th }} \text { day } \\ \text { METHOD OF } & \text { TREATMENT: }\end{array}$

Swedana Karma:

Poorva Karma: Pada Abhyanga with Nirgundi Taila Pradhana Karma: Ishtika Sweda were performed till Samyak Lakshanas were seen in group A and Group B Nadi Sweda were performed till Samyak Lakshanas were seen

Paschat Karma: the patient was advised to take a rest.

Shamana: Rasnadi Guggulu $500 \mathrm{mg}$ twice daily with Ushnodaka

Assessment criteria:

Grading for Assessing Subjective and Objective Parameters:

The improvement of patients was assessed based on relief in the signs and symptoms of the disease. To analyze the efficacy of the drug, marks were given statistically to each symptom. According to the severity of the symptoms, the grading was given as below.

\section{Scores of Specific Symptoms:}

\section{Subjective Parameters:}

\section{Pain Grading:}
a. No pain
b. Pain while walking a few steps after rest
c. Pain while walking for longer period of time
d. Continuous unrelenting pain while walking
e. Unrelenting pain while walking and during rest 4

\section{OBJECTIVE PARAMETERS:}
a. Tenderness with no physical response 1
b. Tenderness with grimace, vince or flinch 2
c. Tenderness with withdrawal (positive jump sign) 3
d. Non - noxious stimuli 4
e. (example: superficial palpation, gentle percussion)
f. results in patient withdrawal or patient refusal to be palpated due to pain.

\section{OBSERVATIONS AND RESULTS}

Effect of therapy on the subjective parameter - Pain and Objective parameter - Tenderness was examined and recorded before treatment, after $7^{\text {th }}$ day and after treatment. The analysis of the effects of therapy are as follows: 
Table 1: Effect of treatment within the groups based on pain

Table: Effect of Treatment within the Groups on Pain

\begin{tabular}{|c|c|c|c|c|c|c|}
\hline \multirow{2}{*}{$\begin{array}{l}\text { Assessment Observations Recorded } \\
\text { on }\end{array}$} & \multicolumn{3}{|c|}{ Descriptives } & \multicolumn{3}{|c|}{ Repeated Measures of ANOVA test } \\
\hline & $\mathrm{N}$ & $\begin{array}{l}\text { Mean } \quad(\mathrm{Me}- \\
\text { dian) }\end{array}$ & $\pm \mathrm{SD}$ & Change in \% & $\begin{array}{l}\text { Friedman statis- } \\
\text { tics }\end{array}$ & $\mathrm{P}$ \\
\hline \multicolumn{7}{|l|}{ Ishtika Sweda } \\
\hline BT & 20 & 2.35 & 0.81 & & \multirow[t]{3}{*}{$\mathrm{F}=36.369$} & \multirow[t]{3}{*}{$<0.0001 *$} \\
\hline After 7 days & 20 & 1.10 & 0.55 & $1.25(53)$ & & \\
\hline AT & 20 & 0.65 & 0.59 & $1.7(72)$ & & \\
\hline \multicolumn{7}{|l|}{ Nadi Sweda } \\
\hline BT & 20 & 2.15 & 0.81 & & \multirow[t]{3}{*}{$\mathrm{F}=33.818$} & \multirow[t]{3}{*}{$<0.0001 *$} \\
\hline After 7 days & 20 & 1.2 & 0.62 & $1.0(47)$ & & \\
\hline AT & 20 & 0.70 & 0.66 & $1.5(72)$ & & \\
\hline
\end{tabular}

Effect of Treatment within the Group on Pain in Group A: the mean before treatment is 2.35 and it has reduced to 1.10 after the $7^{\text {th }}$ day and after treatment, it was found to reduce to 0.65 . It was found a highly significant difference between before, after the $7^{\text {th }}$ day and at the end of treatment ( $p=<0.0001)$. It implied the effect of treatment was found in Pain.
Effect of Treatment within the Group on Pain in Group B: It was observed that the mean was 2.15 and has reduced to 1.2 after the $7^{\text {th }}$ day and after treatment, it was found to be reduced to 0.70 . It was found a highly significant difference between before, after the $7^{\text {th }}$ day and at the end of treatment $(\mathrm{p}=<0.0001)$. it implied the effect of treatment was found in Pain

Graph 1: Effect of treatment within the groups based on pain

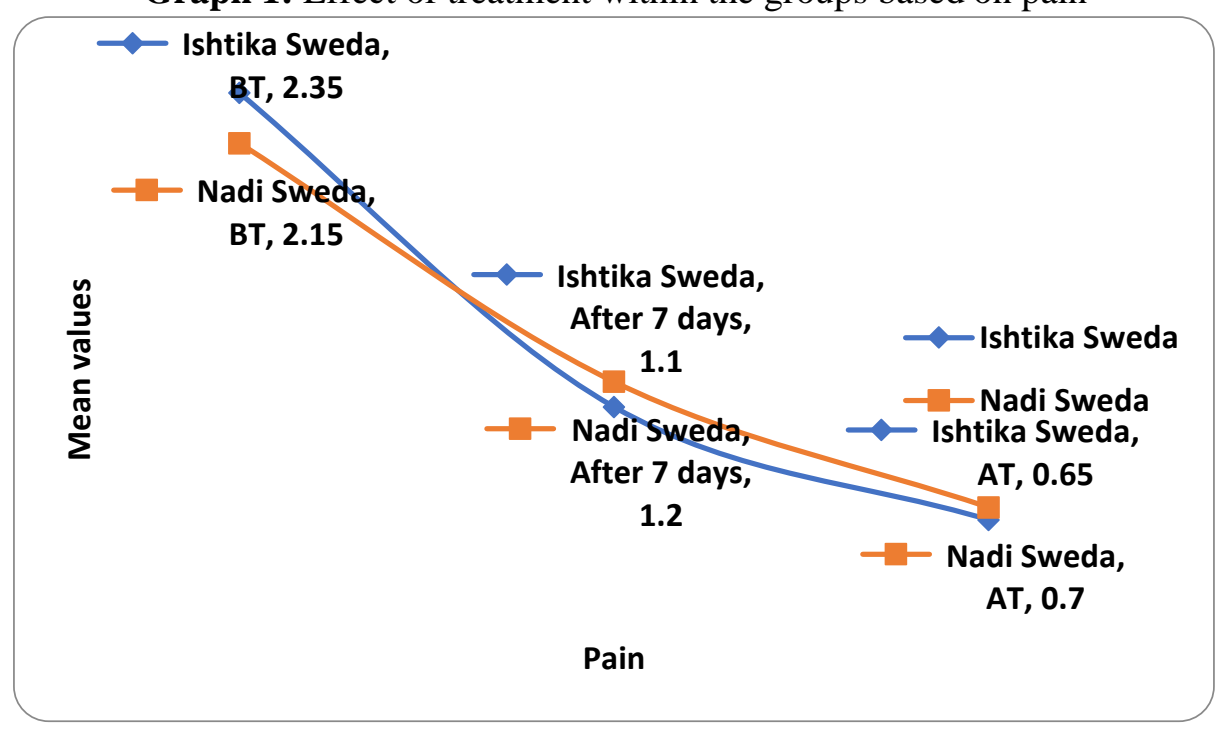

Table 2: Multiple Comparisons of pain

Table: Multiple Comparisons of Pain

Dunn's Post hoc test

Group

Ishtika Sweda
Comparison between

BT

\begin{tabular}{l|l} 
After 7 days \\
AT
\end{tabular}

Sig.
$<0.00$
$<0.00$
Remarks

HS

HS 


\begin{tabular}{|l|l|l|l|l|}
\hline \multirow{2}{*}{ Nadi Sweda } & After 7 days & AT & $>0.05$ & NS \\
\hline & BT & After 7 days & $<0.001$ & HS \\
\hline & & AT & $<0.01$ & HS \\
\cline { 2 - 5 } & After 7 days & AT & $>0.05$ & NS \\
\hline \multirow{2}{*}{ NS-No Significant HS-Highly significant } & & & \\
\hline
\end{tabular}

Table 3: Effect of treatment within the groups on tenderness

Table: Effect of Treatment within the Groups on Tenderness

\begin{tabular}{|c|c|c|c|c|c|c|}
\hline \multirow{2}{*}{$\begin{array}{l}\text { Assessment Ob- } \\
\text { servations Rec- } \\
\text { orded on }\end{array}$} & \multicolumn{3}{|c|}{ Descriptives } & \multicolumn{3}{|c|}{ Repeated Measures of ANOVA test } \\
\hline & $\mathrm{N}$ & Mean (Median) & $\pm \mathrm{SD}$ & Change in \% & $\begin{array}{l}\text { Friedman } \\
\text { tistics }\end{array}$ & $\mathrm{P}$ \\
\hline \multicolumn{7}{|l|}{ Ishtika Sweda } \\
\hline BT & 20 & 1.25 & 1.099 & & \multirow[t]{3}{*}{$F=22.400$} & \multirow[t]{3}{*}{$<0.0001 *$} \\
\hline After 7 days & 20 & 0.30 & 0.470 & $0.75(71.4)$ & & \\
\hline AT & 20 & 0.10 & 0.308 & $0.95(90.4)$ & & \\
\hline \multicolumn{7}{|l|}{ Nadi Sweda } \\
\hline BT & 20 & 1.05 & 0.76 & & \multirow[t]{3}{*}{$\mathrm{F}=31.388$} & \multirow[t]{3}{*}{$<0.0001^{*}$} \\
\hline After 7 days & 20 & 0.40 & 0.68 & $0.85(81)$ & & \\
\hline $\mathrm{AT}$ & 20 & 0.2 & 0.523 & $0.9(86)$ & & \\
\hline
\end{tabular}

HS - Highly significant

Effect of Treatment within the Group on Tenderness in Group A: The mean before treatment is 1.25 and it has reduced to 0.30 and then 0.10 after the $7^{\text {th }}$ day and after treatment respectively. It was found a highly significant difference between before after the $7^{\text {th }}$ day and at the end of the treatment ( $\mathrm{p}=0.0001)$, it implied the effect of treatment was found in tenderness.
Effect of Treatment within the Group on Tenderness in Group B: The mean before treatment is 1.05 and it has reduced to 0.40 and then 0.2 after the $7^{\text {th }}$ day and after treatment respectively. It was found a highly significant difference between before after the $7^{\text {th }}$ day and at the end of the treatment ( $\mathrm{p}=0.0001)$, it implied the effect of treatment was found in tenderness.

Graph 2: Effect of treatment within the groups on tenderness

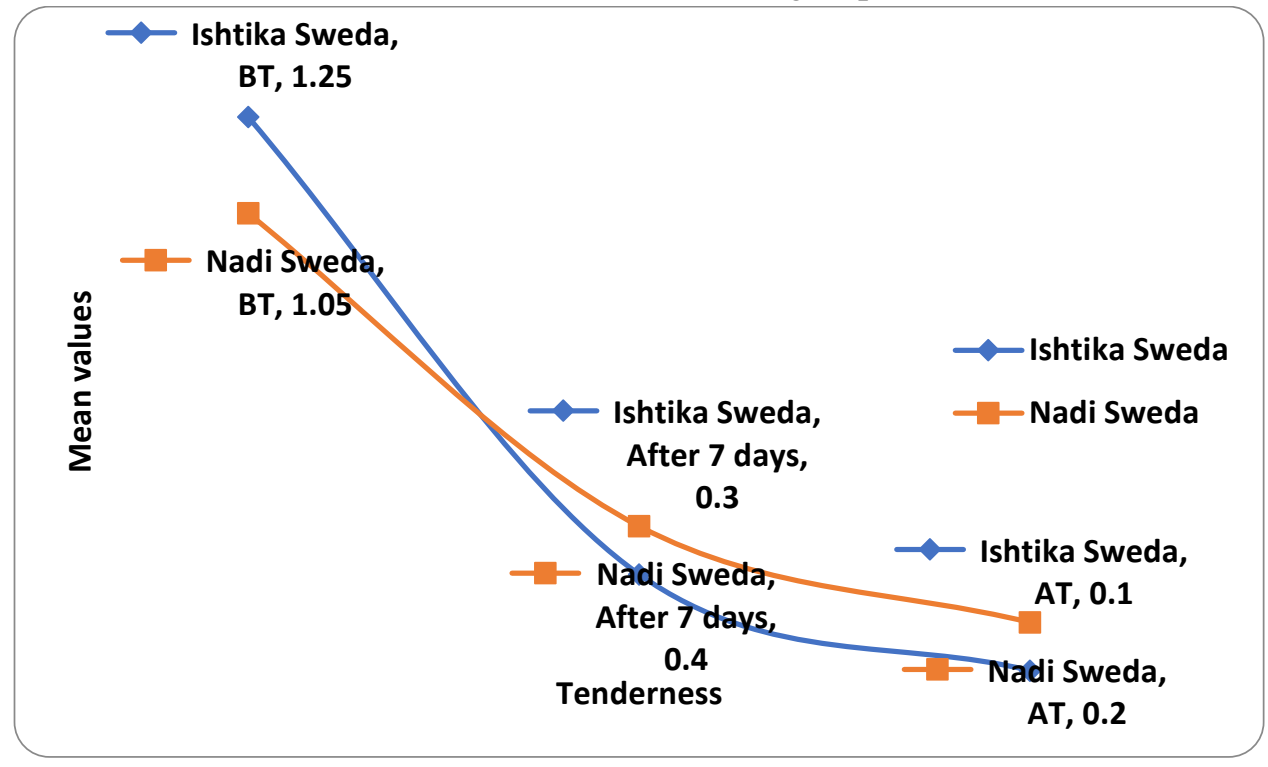


Table 4: Multiple Comparisons of Tenderness

Table: Multiple Comparisons of Tenderness

Dunn's Post hoc test

\begin{tabular}{|l|l|l|l|l|}
\hline \multirow{2}{*}{ Group } & \multicolumn{2}{|l|}{ Comparison between } & Sig. & Remarks \\
\hline \multirow{2}{*}{ Ishtika Sweda } & BT & After 7 days & $<0.05$ & Sign \\
\cline { 3 - 4 } & & AT & $<0.01$ & HS \\
\cline { 2 - 4 } & After 7 days & AT & $>0.05$ & NS \\
\hline \multirow{2}{*}{ Nadi Sweda } & BT & After 7 days & $<0.001$ & HS \\
\cline { 2 - 4 } & AT & $<0.001$ & HS \\
\cline { 2 - 4 } & After 7 days & AT & $>0.05$ & NS \\
\hline
\end{tabular}

NS-No Significant HS-Highly significant

From the above results, it was found that both Nadi Sweda and Ishtika Sweda were equally effective in the treatment of Vatakantaka.

\section{DISCUSSION}

Vatakantaka is the disease affecting the vata and asthi dhatu, thus affecting the heel region of the foot characterized by very special symptom that is pricking pain in the heel which is very intense in the first few steps after getting up and relieve after a time duration which is more severe in the early morning. We can correlate the symptom with the disease calcaneal spur.

The exact aetiology is not known but, as our country is not socially economically completely developed, the majority of our people are travelling through public transport or pedestal walking or under physical exertion like walking barefoot, long-standing will lead to a tremendous amount of strain on foot leading to Khavaigunya in the heel leading to the disease $\mathrm{Va}$ takantaka. Hence to solve this social and painful condition and in a way treat it with ease, simple and costeffective management of the disease has been selected for the study.

Vatakantaka is one among the vatavyadhi according to different classics except Charakacharya included it under Swedana Saadhya vyadhis. Many of the treatment modalities have been explained by different Acharyas like Dahana, Snehana, Raktavasechana, swedana etc. Among them, Abhyanga followed by Swedana by Ishtika or Nadi sweda are most convenient, easy and cost-effective. Hence, they are taken for the study to evaluate their comparative effectiveness. Our Acharyas have mentioned the Nidanas for
Vatakantaka as Vishama and Shrama which remain true till today. It can be seen that activities like walking long distances, standing for a longer duration of time, barefoot walk etc lead to vatavyadhi and khavaigunya of asti.

In this clinical condition, we see that astikshaya is the main pathological entity although the development of extra bony projection seems to be astivruddhi it is not. Acharya Chakrapani and Dalhana classify such growth as astikshaya, as all vatavyadhi are difficult to treat, so as Vatakantaka as it is also vatavyadhi. In the context of vatavyadhi usage of Ishtika Sweda, Nadi Sweda, Nirgundi taila and Rasnadi Guggulu are clearly explained. In all the Vatavyadhis, abhyanga being the most important procedure acting as vatahara, shotahara and is thus it is done using Nirgundi taila which is having katu tikta rasa, having same properties will alleviate the disease.

Swedana: Swedana is an extensively used panchakarma procedure that does the vasodilation leading to increased blood flow to the tissue and improvises tissue healing. Swedana does the srotoshuddhi and aamapachana to relieve stiffness. In the first group, swedana is done using Kanji and it is having properties like ushna guna which will help to alleviate the symptoms in Vatakantaka. In group B the swedana is done by nadi sweda using vatahara drugs which help to relieve pain and stiffness.

\section{Mode of action of Swedana:}

- Swedakarakatva: As Sweda is type of trimala it helps to eliminate the dushita dosha. Since Swedana drugs have ushna and tikshnaguna, they are capable of penetrating the microcirculatory 
channels, where they activate the sweat glands to produce more sweat. After dilatation of microchannels, laghu and saraguna of these drugs enable them to act on the snigdhadosha.

The physiological effect of Swedana Therapy ${ }^{(10)}$ : Increased vasodilatation:

In almost all areas of the body, the skin blood vessels become intensely dilated. This is caused by inhibition of the sympathetic centres in the posterior hypothalamus that causes vasoconstriction. Full vasodilatation can increase the rate of heat transfer to the skin by as much as eight-fold. So, it can be inferred that the ushnaguna of swedana karma leads to stimulation of the sympathetic nervous system and there is vasodilatation. Ushnaguna also increases the circulation of Rasa and Rakta in the body.

\section{Changes in nerve conditions:}

Increased temperature changes nerve conduction velocity and firing rate, it decreases the conduction latency of both sensory and motor nerves. Nerve conduction velocity has been reported to increase by approximately 2 metres/second for every $1{ }^{\circ} \mathrm{C}$ increase in temperature. Elevation of muscle temperature has been shown to result in in-

$>$ decreased firing rate of type II muscle spindle efferents and gamma efferents.

$>$ an increased firing rate of type lb fivers from Golgi tendon organs.

$>$ a reduction in the firing rate of alpha motor neurons.

$>$ decrease in gamma neuron activity which causes the stretch on the muscle spindles to decrease.

$>$ decreased alpha motor neuron activity.

All these leads to relaxation of muscle contraction and thus to a reduction in muscle spasm.

- Increase in pain threshold:

- The vasodilatation and increased blood flow cause increased oxygen and nutrients supply to speed healing and relax muscles. This alters the perception of pain along with the inhibitory gating effect on the transmission of pain sensation to spinal cord level by cutaneous thermoreceptors. Thus, resulting in an increased pain threshold.
Rasnadi Guggulu: Rasnadi Guggulu has all properties like vatakaphanashaka, deepana, pachana, shotaghna and vedanasthapana. These properties are likely to break down the pathogenesis of vatakantaka and thus may arrest the progression of the disease.

\section{CONCLUSION}

The disease is mainly due to excessive stress on the heel which vitiates vata and asti. Many treatment modalities are explained in Samhitas. Swedana is one of such modalities of treatment of vatakantaka. The action of both the treatment is equivalent in this study. The combined effect of swedana along with shamanoushadi helps in relieving the disease. In both groups, the intensity of pain was reduced. Although Ishtika swedana is a standard procedure for vatakantaka, Nadi swedana also shows almost similar results while treating vatakantaka. Swedana with its ushna guna pacifies the shoola and stambha. Nirgundi taila as snehana does vatashamana and rasnadi guggulu as shamanoushadhi does shoolahara. Both the procedures of treatment not only proved significant but also easy, cost-effective and non-invasive. There were no side effects observed either during the treatment or after the treatment was completed. In chronic cases, once the symptoms subside after the treatment, there is a chance of re-occurrence.

\section{REFERENCES}

1. Acharya Sushruta, Sushruta Samhita by Kaviraj Ambikadatta Shastri, vol-I, $14^{\text {th }}$ edition 2003, Chaukhamba Sanskrit sansthan Varanasi, Su, Ni 1/79, Page no: 235.

2. Vagbhata's, Astanga Hrdayam Sarvanga Sundari Vykhya, by Shri Lal Chandra Vaidhya, Bharateeya Sanskriti Granthamala, A.Ni 15/53, page no:353.

3. Shri Madhavakara, Madhava nidhan by Yadunandan Upadhyaya, purvardha, part-I, Reprint 2013, Chowkhamba Sanskrit series Varanasi, shloka no 22/61, page no-442.

4. Somen Das- Textbook Surgery. S. Das publications, Kolkata. Sixth Edition 2010. p-375.

5. Ozan Beytemür, MehmetOr̈cü.: The age-dependent change in the incidence of the calcaneal spur. Acta Orthopaedica et Traumatologica Turcica, 2018 52(5), 367-371. 
6. Toumi et al.: Changes in prevalence of calcaneal spurs in men \& women: a random population from a trauma clinic. BMC Musculoskeletal Disorders 2014 15:87.

7. Vaidhya Shri Laksmipati Sastri, Yogaratnakara, by Bhishgratna Shri Brahmashankar Shastri, $3^{\text {rd }}$ edition 1983, Chaukhamba Sanskrit Sansthan, Varanasi, Page no: 531

8. Acharya Priyavrat Sharma, Dravyaguna Vijnana, Revised golden jubilee edition-2007, Chaukhambha Visvabharati, Varanasi, page no: 413.

9. Dr Madham Shetty Suresh Babu, Yogaratnakara (VolI) $2^{\text {nd }}$ edition-2011, Varanasi, Choukhambha Krishnadas Academy

10. Panchakarma Parigyan, A textbook on Panchakarma by Vd. Sarvesh Kumar Singh and Vd. Kshipra Rajoria, $1^{\text {st }}$ edition-2019, Chaukhambha Prakashan, Varanasi, Page-no: 195

\section{Source of Support: Nil \\ Conflict of Interest: None Declared}

How to cite this URL: Gouri Tanksali \& Uma Patil: A Comparative Clinical Study Of Ishtika Sweda And Nadi Sweda Along With Rasnadi Guggulu In The Management Of Vatakantaka. International Ayurvedic Medical Journal \{online\} 2021 \{cited September 2021\} Available from: http://www.iamj.in/posts/images/upload/2021 2028.pdf 